University of Nebraska - Lincoln

DigitalCommons@University of Nebraska - Lincoln

\title{
The utility of transactional and transformational leadership for predicting performance and satisfaction within a path-goal theory framework
}

\author{
Robert P. Vecchio \\ University of Notre Dame, vecchio.1@nd.edu \\ Joseph E. Justin \\ Claremont Graduate University \\ Craig L. Pearce \\ University of Nebraska - Lincoln, cpearce2@unl.edu
}

Follow this and additional works at: https://digitalcommons.unl.edu/managementfacpub

Part of the Management Sciences and Quantitative Methods Commons

Vecchio, Robert P.; Justin, Joseph E.; and Pearce, Craig L., "The utility of transactional and transformational leadership for predicting performance and satisfaction within a path-goal theory framework" (2008). Management Department Faculty Publications. 75.

https://digitalcommons.unl.edu/managementfacpub/75

This Article is brought to you for free and open access by the Management Department at DigitalCommons@University of Nebraska - Lincoln. It has been accepted for inclusion in Management Department Faculty Publications by an authorized administrator of DigitalCommons@University of Nebraska - Lincoln. 


\title{
The utility of transactional and transformational leadership for predicting performance and satisfaction within a path-goal theory framework
}

\author{
Robert P. Vecchio, ${ }^{1}$ Joseph E. Justin, ${ }^{2}$ and Craig L. Pearce ${ }^{2}$ \\ 1. University of Notre Dame, South Bend, Indiana, USA \\ 2. Claremont Graduate University, Claremont, California, USA \\ Corresponding author - Robert P. Vecchio, Department of Management, University \\ of Notre Dame, Notre Dame, IN 46556, USA; email vecchio.1@nd.edu
}

\begin{abstract}
In a test of hypotheses derived from the integration of principles of path-goal theory (House, 1996) and transformational leadership theory (Bass, 1985), data collected from 179 high school teachers and their principals were examined with hierarchical regression analysis. Augmentation analysis indicated that transactional leadership had a stronger role in explaining unique criterion variance beyond the contribution of transformational leadership, than did transformational leadership relative to transactional leadership. In addition, both the transactional and transformational leadership had a negative interactive relationship for predicting the outcome of performance, such that leader vision and leader intellectual stimulation were more positively correlated with employee performance when leader use of contingent reward was low. These augmentation effects, in conjunction with the findings of negative moderation, suggest that transactional leadership may have greater potential predictive value than previously assumed.
\end{abstract}

Two of the major approaches to understanding leadership are reflected in the principles of path-goal leadership theory (Evans, 1970; House, 1971; House \& Dessler, 1974; House \& Mitchell, 1974; Schriesheim \& Neider, 1996; Wofford \& Liska, 1993) and transformational leadership theory (Bass, 1985; Bass, 1990; Bass \& Avolio, 1993; Conger \& Kanungo, 1987). Although the publication of path-goal theory predates transformational leadership theory, it has received comparatively less attention in the empirical literature. In an updated revision of the original theory, House (1996) developed a number of propositions that are intended to both clarify and extend the theory, and thereby hopefully revitalize research on the theory. Of special interest is a proposal by House (p. 345) that links aspects of path-goal theory to aspects of transformational leadership. Specifically, House proposed that transactional leadership (i.e. a reliance on contingent rewards to induce subordinate performance) is exercised when leaders utilize extrinsic rewards in order to exert influence. But by re- 
fraining from the use of extrinsic rewards that are contingent on subordinate performance, the impact of value-based (i.e. transformational) leadership should be enhanced. Among the features that define value-based leadership, House (p. 343) identified articulation of a vision, high performance expectations, and frequent positive evaluations as being of particular importance (House \& Shamir, 1993). In support of his view of value-based leadership, House cited empirical evidence provided by Bass and Avolio (1994) of powerful effects on motivation and performance, with effect sizes of .40-.50.

House's proposition of the interplay of contingent personal reward (an important aspect of transactional leadership) with aspects of transformational leadership is relatively novel, as it posits a negative interaction between contingent reward and transformational leadership in enhancing follower outcomes (i.e. the relationship of aspects of transformational leadership should be stronger for low contingent reward, relative to high contingent reward). In prior research, the proposed association of transformational and transactional leadership has been one of augmentation. The augmentation hypothesis argues that transformational leadership will significantly predict leadership criteria after controlling for transactional leadership. A recent metaanalysis by Judge and Piccolo (2004) that examined the augmentation hypothesis reported evidence that generally supported the augmentation hypothesis.

In the only study to test House's proposed negative interaction between transactional and transformational leadership, Schriesheim, Castro, Zhou, and DeChurch (2006) examined the responses of 295 state social services agency employees (selected from 40 groups) to survey items (taken from Podsakoff, MacKenzie, Moorman, \& Fetter, 1990) that measured leader use of contingent reward, articulation of vision, appropriate modeling, fostering group goal acceptance and high performance expectations. For the outcome measures of supervisor ratings of job performance and employee reports of job satisfaction, Schriesheim et al. (2006) did not find support for House's proposed interaction or for Bass and Avolio's proposed augmentation effect. Subsequent analyses by Schriesheim et al. did lead the authors to conclude that a form of augmentation effect could be claimed for a positive moderator effect, and that those relationships which were identified occurred at an individual (rather than a group) level of analysis (Schriesheim, Cogliser, \& Neider, 1995). However, Schriesheim et al. did conclude that they found no support for House's proposed interaction within the revised path-goal theory, or for the additive augmentation hypothesis originally offered by Bass (1985) and his associates (Bycio, Hackett, \& Allen, 1995; Waldman, Bass, \& Yammarino, 1990).

In their call for further research on this topic, Schriesheim et al. acknowledged the importance of focusing on a relevant level of analysis and obtaining criteria data on variables that are not from the same source as the predictor variables. In this spirit, the present study sought to test both the augmentation hypothesis and the proposed interaction of transactional and transformational leadership (i.e. a negative moderation effect of transactional leadership with transformational leadership).

Hypothesis 1: Transformational leadership positively augments the relationship between transactional leadership and the outcomes of employee performance and satisfaction, as manifested by accounting for additional unique criterion variance; and

Hypothesis 2: Contingent reward negatively moderates the relationship between transformational leadership and the outcomes of employee performance and satisfaction, such that the relationship of transformational leadership will be more positive when contingent reward is comparatively low. 


\section{Method \\ Subjects and Site}

As the concepts of transformational and transactional leadership have received much attention in recent years within the area of educational leadership (Barnett, McCormick, \& Conners, 2001; Eden, 1998; Leithwood, 1994; Leithwood \& Jantzi, 1997), high school teachers and their principals in the California public school system were examined as part of a project designed to achieve a better understanding of teacher-principal relations (Ingram, 1997). Using randomly selected schools identified within the California Public School Directory (California Department of Education, 2001), surveys were distributed initially to the principal of each school. Subsequently, a different survey was mailed to each of the five departmental (English, History, Math, P.E. and Science) head teachers at each responding principal's institution. Of 491 principals who were contacted, $223(45.3 \%)$ returned completed surveys. Of 1,060 confidential questionnaires that were mailed to the head teachers, a total of 342 were returned. In order to have comparable data for responding principals and their teachers, 179 teacher-principal dyads were randomly selected for further study via a sampling procedure based on a table of random numbers (Lindquist, 1940). One leader-subordinate dyad was selected from each institution in order to avoid potential problems associated with nonindependence of respondents' descriptions of a common leader's behavior. This sampling strategy was employed because, as has been demonstrated in a number of instances, nested data structures can generate parameter estimates that are incorrect (cf. Bliese, 2000a; Hofmann, 1997; Raudenbush \& Bryk, 2002).

\section{Measures}

The rationale for selecting the criteria and predictors for the present analyses was grounded in prior research and theory. Among the variables incorporated in the present survey as criteria were the two variables, namely employee performance and job satisfaction, that Schriesheim et al. focused on in their recent research. For predictors, leader use of contingent personal reward, performance expectations, intellectual stimulation and participative goals were included, as guided by House's theorizing and Schriesheim et al.'s research. Although Schriesheim et al. did not study intellectual stimulation (which is a component of Bass's view of transformational leadership) or participative goals (which is emphasized by House in his revised path-goal theory), the present study provides an opportunity to both replicate Schriesheim et al.'s research while extending it to examine additional potential predictors.

The specific criteria in the present study included: a three-item measure of job satisfaction, developed by Cammann, Fichman, Jenkins, and Klesh (1983) (sample item: All in all, I am satisfied with my job); and a three-item measure of job performance (sample item: All things considered, this teacher performs his/her job the way I like to see it performed), with response options of 1 = strongly disagree, 2 = disagree, 3 = neither disagree nor agree, $4=$ agree, $5=$ strongly agree.

Present predictors (taken from measures developed by Podsakoff, Toder, Grover, \& Huber, 1984; Podsakoff, Bommer, Podsakoff, \& MacKenzie, 2005; Podsakoff, MacKenzie, \& Bommer, 1996; Podsakoff et al., 1990) included three-item measures of the following constructs: vision (sample item: My principal provides a clear vision of where our school is going); performance expectations (sample item: My principal expects me to perform at my highest level); intellectual stimulation (sample item: My principal encourages me to rethink ideas that had never been questioned before); participative goals (sample item: My prin- 
cipal works with me to develop my performance goals); and contingent reward (sample item: My principal commends me when I do a better-than- average job), with response options of 1 = strongly disagree, 2 = disagree, 3 = neither disagree nor agree, $4=$ agree, 5 = strongly agree.

\section{Check for potential nonindependence in the data}

As noted earlier, responding teachers were associated, or nested, with principals. Because the full set of respondents is nonindependent, intra-class coefficients were calculated to estimate whether group-level analyses would be necessary (Bliese, 2000b). The ICC(1) coefficients (i.e. the amounts of variance in an individual's responses that could be explained by group membership) for the variables of satisfaction, performance, vision, intellectual stimulation, participative goals, expectations and contingent reward were .02, $.13, .29, .12, .13, .09$ and .07, respectively. The ICC(2) coefficients (i.e. estimates of the reliability of the group means) for the same variables were $.05, .23, .42, .20, .21, .16$ and .11, respectively (all of these values were below the accepted cut-off level of .70, Glick, 1985). Hence, these values indicate that there was insufficient variance between principals combined with low stabilities of the group means to require a multi-level approach. Moreover, the data-set included an average of roughly two lead teachers per school (1.9 respondents per principal). Thus, even if all lead teachers had responded in all schools (a maximum of five teachers per school), the number of cases per school would still be below the recommended minimum number of cases per group in order to conduct HLM (Hofmann, 1997; Hox, 1998; Kreft, 1996; Raudenbush \& Liu, 2000). For all these reasons, the present analyses focused on the 179 principals with one lead teacher sampled per principal.

\section{Confirmatory factor analyses}

In order to demonstrate the distinct nature of the teachers' leadership assessments on the five dimensions, confirmatory factor analysis was employed. Results for a five-factor model $\left(\chi^{2}=154.02, d f=80, p<.01\right)$ with overall fit Normed Fit Index $=.98$, Tucker-Lewis Index $=.99$, Comparative Fit Index $=.99$ and RMSEA $=.07$ were superior to the results for a one-factor model $\left(\chi^{2}=669.26, d f=90, p<.01\right)$ with Normed Fit Index $=.92$, TuckerLewis Index $=.91$, Comparative Fit Index $=.93$ and RMSEA $=.19$. The difference in $\chi^{2}$ between the two models $(669.26-154.02=515.24, d f=10, p<.01)$ further indicated a superior fit for the five-factor model. In addition, all of the lambda weights for the items in the five-factor model were greater than .50. Thus, the results of the CFAs showed that the five leadership dimensions should be treated as reasonably distinct constructs.

\section{Results}

The means, standard deviations, internal reliabilities, and intercorrelations of the variables of interest are presented in Table 1. It is notable that the correlations between contingent reward and the outcomes of performance and satisfaction typically exceeded that of the correlations of the same outcomes with the transformational leadership dimensions. ${ }^{1}$ This suggests that transactional leadership has inherent, and comparable, utility

1. It is also worthy of note that the present correlations of contingent reward with performance and satisfaction ( $r^{\prime} \mathrm{s}=.34$ and .36 ) correspond to the mean correlations reported by Podsakoff et al. (2005) in a meta-analytic review of the literature ( $r$ 's $=.20$ and .44$)$. The replication of these associations offers some assurance that the obtained responses constitute meaningful data. 
Table 1. Means, standard deviations, and intercorrelations

\begin{tabular}{|c|c|c|c|c|c|c|c|c|c|}
\hline \multirow[b]{2}{*}{ Variable } & \multirow[b]{2}{*}{ Mean } & \multirow[b]{2}{*}{$S D$} & \multicolumn{7}{|c|}{ Intercorrelations } \\
\hline & & & 1. & 2. & 3. & 4. & 5. & 6. & 7. \\
\hline 1. Vision & 10.86 & 3.34 & $(.93)$ & & & & & & \\
\hline 2. Intellectual stimulation & 10.43 & 2.68 & $.72 * *$ & $(.81)$ & & & & & \\
\hline 3. Participative goals & 10.05 & 2.85 & $.42 * *$ & $.52 * *$ & $(.90)$ & & & & \\
\hline 4. Expectations & 12.19 & 1.95 & $.52 * *$ & $.42 * *$ & $.32 * *$ & $(.71)$ & & & \\
\hline 5. Contingent reward & 11.22 & 2.80 & $.57 * *$ & $.57 * *$ & $.49 * *$ & $.36 * *$ & $(.87)$ & & \\
\hline 6. Performance (supervisor) & 12.59 & 2.78 & $.32 * *$ & $.31 * *$ & $.21^{* *}$ & .11 & $.34 * *$ & $(.93)$ & \\
\hline 7. Satisfaction & 13.44 & 2.06 & $.38 * *$ & $.29 * *$ & $.21 * *$ & $.18^{*}$ & $.36 * *$ & $.26 * *$ & $(.78)$ \\
\hline
\end{tabular}

Coefficient a's are on the primary diagonal.

$* p<.05 ; * * p<.01$

as a predictor. However, the question of whether transactional leadership and transformational leadership are able to uniquely account for criterion variance beyond the contribution of the other dimension as a predictor (i.e. Hypothesis 1) requires a formal augmentation analysis, wherein each type of leadership is added as a predictor after initially controlling for the contribution of the alternative leadership dimension.

Tables 2 and 3 summarize the regression results for the performance and satisfaction dependent variables, respectively. In these tables, indicators of transformational leadership are entered in step 1, followed by the transactional leadership measure as part of a test of the augmentation hypotheses (Hypothesis 1). The unstandardized beta weights at step 2, for both outcome variables, indicate that transactional leadership contributed to explaining criterion variance after controlling for the predictive contribution of transfor-

Table 2. Regression results for performance

\begin{tabular}{|c|c|c|c|c|c|c|}
\hline \multirow[b]{2}{*}{ Step } & \multirow[b]{2}{*}{ Predictors } & \multicolumn{5}{|c|}{ Unstandardized betas } \\
\hline & & Step 1 & Step 2 & Step 3 & $R^{2}$ & $\Delta R^{2}$ \\
\hline 1. & Vision (V) & $.25 * *$ & $.14+$ & .11 & $.10 * *$ & $.10 * *$ \\
\hline 2. & Contingent reward (C) & & $.23 * *$ & .14 & $.14 * *$ & $.04 * *$ \\
\hline 3. & $\mathrm{~V} \times \mathrm{C}$ Interaction & & & $2.05 *$ & $.17 * *$ & $.03 *$ \\
\hline 1. & Expectations (E) & .15 & 2.04 & 2.04 & .01 & .01 \\
\hline 2. & Contingent reward (C) & & $.08 * *$ & $.34 * *$ & $.12 * *$ & $.11^{* *}$ \\
\hline 3. & $\mathrm{E} \times \mathrm{C}$ Interaction & & & .00 & $.12 * *$ & .00 \\
\hline 1. & Intellectual stimulation (I) & $.32 * *$ & $.16+$ & .14 & $.10 * *$ & $.10 * *$ \\
\hline 2. & Contingent reward (C) & & $.25 * *$ & $.17+$ & $.14^{* *}$ & $.04 * *$ \\
\hline 3. & I $\times$ C Interaction & & & $2.05^{*}$ & $.17 * *$ & $.03 *$ \\
\hline 1. & Participative goals (P) & $.22 * *$ & .08 & .07 & $.05 * *$ & $.05 * *$ \\
\hline 2. & Contingent reward (C) & & $.29 * *$ & $.28 * *$ & $.12 * *$ & $.07 * *$ \\
\hline 3. & $\mathrm{P} \times \mathrm{C}$ Interaction & & & 2.04 & $.13^{* *}$ & .01 \\
\hline
\end{tabular}

Unstandardized beta for contingent reward when entered as the initial predictor at step $1=.34 ; p<.01 ; R^{2}=.13 ; p<.01$.

$+p<.10 ; * p<.05 ; * * p<.01$ 
Table 3. Regression results for satisfaction

\begin{tabular}{|c|c|c|c|c|c|c|}
\hline \multirow[b]{2}{*}{ Step } & \multirow[b]{2}{*}{ Predictors } & \multicolumn{5}{|c|}{ Unstandardized betas } \\
\hline & & Step 1 & Step 2 & Step 3 & $R^{2}$ & $\Delta R^{2}$ \\
\hline 1. & Vision (V) & $.25 * *$ & $.18^{* *}$ & $.17 * *$ & $.16 * *$ & $.16 * *$ \\
\hline 2. & Contingent reward (C) & & $.14^{*}$ & .10 & $.19 * *$ & $.03 *$ \\
\hline 3. & $\mathrm{~V} \times \mathrm{C}$ interaction & & & 2.02 & $.20 * *$ & .01 \\
\hline 1. & Expectations (E) & $.21 * *$ & .08 & .06 & $.04 * *$ & $.04 * *$ \\
\hline 2. & Contingent reward (C) & & $.24 * *$ & $.24 * *$ & $.14 * *$ & $.10 * *$ \\
\hline 3. & $\mathrm{E} \times \mathrm{C}$ Interaction & & & 2.02 & $.14 * *$ & .00 \\
\hline 1. & Intellectual Stimulation (I) & $.23 * *$ & .10 & .10 & $.10 * *$ & $.10 * *$ \\
\hline 2. & Contingent reward $(\mathrm{C})$ & & $.21 * *$ & $.21 * *$ & $.16 * *$ & $.06 * *$ \\
\hline 3. & $\mathrm{I} \times \mathrm{C}$ Interaction & & & 2.01 & $.16 * *$ & .00 \\
\hline 1. & Participation goals (P) & $.18 * *$ & .07 & .06 & $.06 * *$ & $.06 * *$ \\
\hline 2. & Contingent reward (C) & & $.23 * *$ & $.22 * *$ & $.14 * *$ & $.08 * *$ \\
\hline 3. & $\mathrm{P} \times \mathrm{C}$ Interaction & & & 2.02 & $.15^{* *}$ & .01 \\
\hline
\end{tabular}

Unstandardized beta for contingent reward when entered as the initial predictor at step $1=.26 ; p<.01 ; R^{2}=.12 ; p<.01$.

$* p<.05 ; * * p<.01$.

mational leadership. The reverse order of initial entry of predictors (summarized in a Note to Tables 2 and 3 for performance and satisfaction, respectively) shows that when the indicator of transactional leadership was entered first, the associated beta always exceeded the betas for transformational leadership. As revealed by the betas at step 2 (which, of course, are invariant to the order in which either predictor was initially entered), there was an indication in seven of eight comparisons (i.e. with the only exception of vision, for the outcome of satisfaction) that the contribution of transactional leadership augmented transformational leadership rather than the reverse.

Hypothesis 2 posited that the relationships between the transformational leadership and the outcomes of performance and satisfaction would be moderated by leader contingent reward, such that the relationships between the dimensions of transformational leadership and the outcomes would be more positive for low contingent reward (i.e. a negative moderator relationship). Moderated regression was performed to examine this prediction by creating multiplicative interaction terms in accordance with the procedures outlined by Aiken and West (1991). More specifically, the predictor and moderator variable in each instance was initially centered around a mean of zero (by subtracting each variable from its respective mean value) before creating the multiplicative term (this practice is recommended to reduce the correlation between the interaction term and the variables comprising the interaction term). Hence, a three-step procedure was followed, where step 1 tested for the effect of the specific transformational leadership predictor, step 2 (as noted earlier) tested for the augmented (additional) effect of contingent reward beyond the effect of the predictor, and step 3 tested for the effect of the interaction of the initial predictor and the augmentation (moderator) variable. As discussed above, support for the augmentation hypothesis is indicated by a significant positive beta weight at step 2, while support for the negative interaction hypothesis is indicated by a significant negative beta weight at step 3 . 


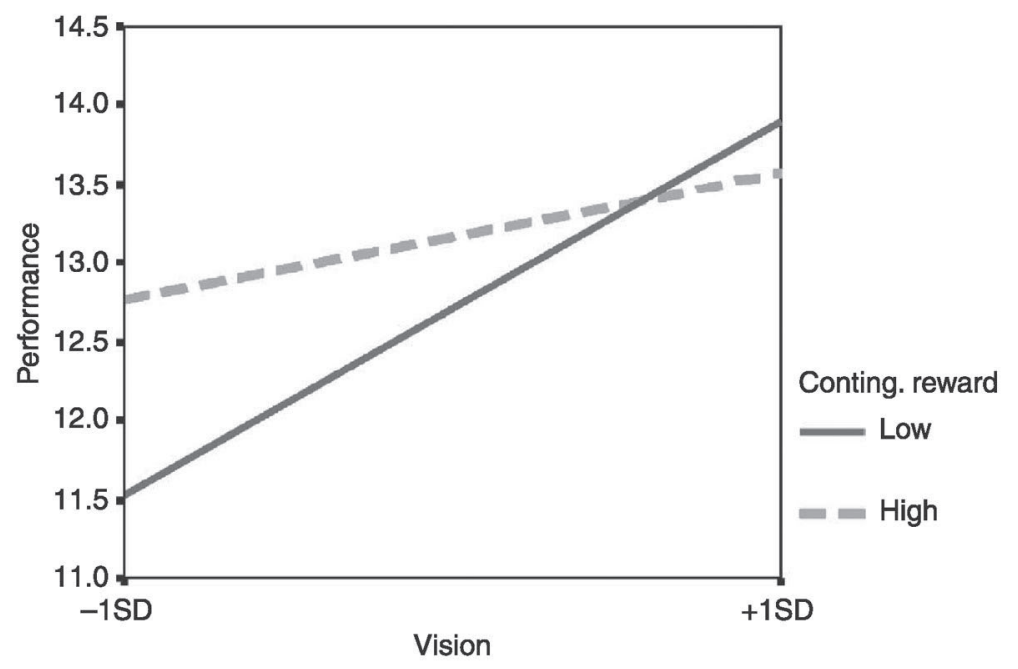

Figure 1. Vision $\times$ reward Interaction: Dependent variable $=$ performance.

Although seven of the eight betas that were tested for interaction were negative in sign, only two significant negative interactions were identified - both significant interactions were for the criterion of performance with the predictors of vision and contingent reward $(\beta=-0.05, p<.05)$, and with the predictors of expectations and contingent reward $(\beta=-0.05, p<.01)$. In order to examine the nature of these significant interactions, median splits were created on the moderating dimension of contingent reward, and separate regressions were calculated for the two levels of the moderator (Cohen, Cohen, West, $\&$ Aiken, 2003). Values at plus and minus one standard deviation from the mean were inserted into these equations to graph the interactions. Figures 1 and 2, which portray the nature of the significant interactions, reveal that the regression slopes were less positive under the high level of the moderator variable (versus the low level of the moderator variable). Therefore, the nature of both observed interactions is supportive of the predicted interaction.

As a further examination of the significant interaction effects, the Johnson and Neyman (1936) technique was employed to compute regions of significance. The regions of significance specify the levels of a variable at which the mean differences are significant. The vision $\times$ contingent reward interaction was disordinal. Therefore, upper and lower bounds were determined. The upper limit (or bound) for the $95 \%$ confidence limit for vision was 12.79 , while the lower limit was 10.07 . Thus, we can state that values for vision exceeding the upper bound (34.3\% of the cases) or the lower bound (36.1\% of the cases) were significantly different from their otherwise comparable cases in that range. For the ordinal (non-crossing) interaction of intellectual stimulation $\times$ contingent reward, a single value was calculated below which values on intellectual stimulation were in a region of significant difference. Specifically, this lower limit value was 11.40 . Hence, $57.5 \%$ of the cases (i.e. the percentage of cases that fell below 11.40) were in a region of significant difference. Therefore, we can conclude for both interactions that substantial proportions of the observed cases were in a region that was associated with significant differences.

As a final check, $t$ tests were computed for each of the slopes graphed in Figures 1 and 2 to determine whether they differed from zero. The $t$ test results indicated that both 


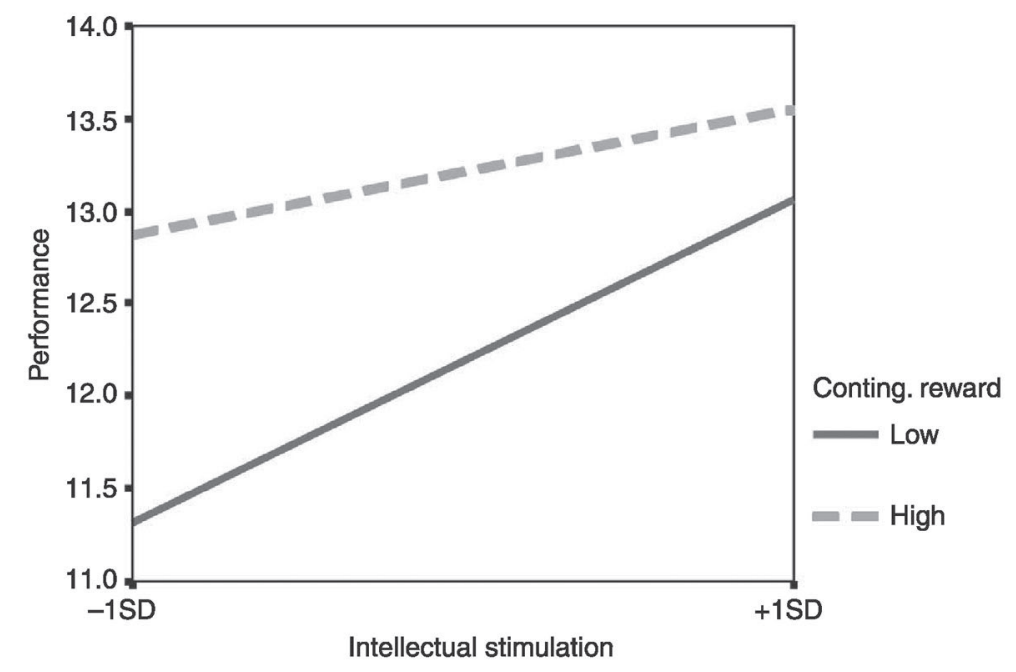

Figure 2. Intellectual Stimulation $\times$ Reward Interaction: Dependent Variable $=$ performance.

slopes for the low level of contingent reward differed significantly from zero (Figure 1, slope $=.25, t=2.14, p<.05$; Figure 2, slope $=.32, t=2.22, p<.05)$, while both slopes for the high level of contingent reward did not differ from zero (Figure 1, slope $=.12, t=1.36$, ns; Figure 2, slope $=.13, t=1.21$, ns). Therefore, the predicted negative moderation hypothesis was fully supported for the transformational leadership dimensions of vision and intellectual stimulation with the criterion of follower performance.

\section{Discussion}

The present findings provide the first support for House's proposed negative moderation hypothesis, relating contingent reward to aspects of transformational leadership in enhancing follower performance. These results are notable in that the data for the outcome variable, performance, were collected independent of the leader behavior data and are, therefore, not subject to the potential criticism that the outcome data may be largely reflective of cognitive or affective dynamics inherent in the survey respondent. As the pattern of the interaction terms (betas) was clearly negative in the regression analyses, it can be contended that the results for both criteria were revealing of some tendency towards negative interaction. However, only the performance outcome revealed significant support. Also, both of the supportive instances (for leader vision and leader intellectual stimulation) revealed an increment in $R^{2}$ that was not especially strong (.03). The outcome of satisfaction did not provide support for the proposed interaction. However, one can argue that job satisfaction is driven by many alternative forces, and does not necessarily reflect leadership as its primary component. Had the present study employed a satisfaction with leadership scale, perhaps the results would have been more supportive.

Another question surrounds what the results might have been had alternative indicators of transactional leadership been studied. Although House discussed contingent reward as a specific dimension, the other dimensions that comprise transactional leadership (i.e. laissez-faire leadership, and management-by-exception positive and management- 
by exception negative) may have revealed additional insights. Also, the present study was limited to only a subset of the various dimensions that have been proposed to define transformational leadership, as a consequence of the practical constraints of controlling survey length and emphasizing construct relevance. When these further transformational dimensions are examined, it is possible that alternative results will be attained. These additional dimensions, which include individualized consideration, idealized influence and inspirational motivation, also need to be analyzed for their theoretical relevance with respect to expected interactions. A further avenue for future research is to examine the potential role of moral aspects of leadership that were identified as components of authentic leadership (Bass, 1997; Howell \& Avolio, 1992). Bass and his associates' views on morality relative to transformational and transactional leadership do suggest that transactional leaders would be expected to engage in unethical practices more so than transformational leaders. Judgments of a leader's ethical posture may play a particularly strong role in influencing follower satisfaction with the leader.

\section{Limitations and strengths}

Although it has become commonplace to critique research that employs retrospective, impressionistic ratings, it is difficult to justify the use of other reports of leader behavior when one considers that it is the leader as viewed by the follower that is most critical to explaining follower behavior in response to the leader (Spector, 1987, 2006). To be sure, dependent measures (e.g. satisfaction) that also rely on same-source data are somewhat suspect (Podsakoff, MacKenzie, Lee, \& Podsakoff, 2003; Podsakoff \& Organ, 1986). However, the present study employed a measure of employee performance that was independent of follower perceptions. Interestingly, it was the independent outcome measure that provided evidence of the predicted negative moderation effect, while the satisfaction outcome measure did not.

The findings of the present study are worth contrasting with those of the prior study by Schriesheim et al. (2006), with particular focus on the differences in the results of the two studies given methodological differences and how the studies varied with respect to location. The earlier study examined members of a single governmental employment setting, while the present study explored a range of distinct, yet still essentially comparable, settings. Also, the earlier study examined a sample of 40 leaders, while the present study examined 179 leaders. The larger number of leaders, in the present study, may have allowed for the examination of a greater range on the dimensions of leader behavior. In addition, the present sampling procedure (wherein unique leader- subordinate dyads were selected) avoided the potential problems associated with nested data structure. A number of differences in the locations of the two studies may help to account for the differences in the obtained results. Perhaps most notably, it may be that educational administrators are more commonly faced with organizational change issues (e.g. via ongoing curriculum development, budget management, and restructuring dynamics) than supervisors of departments within a state social services agency (who may be constrained by bureaucratic forces to maintain a departmental status quo, rather than undertake transformational actions). As a consequence, the dynamics originally proposed by House (1996) may have had a better opportunity to be manifest within the present sample of high school principals.

An important similarity in the findings of both studies lies in the apparent augmentation effect for transactional, rather than transformational, leadership. That is to say, 
in both studies the beta weights for transactional leadership tended to be greater, and more commonly statistically significant, than the weights for transformational leadership. This reverse finding is not without precedent. For example, Bass, Avolio, Jung, and Berson, (2003) reported that transactional leadership augmented transformational leadership, rather than vice versa. And the Judge and Piccolo (2004) meta-analysis reported only on transformational leadership's augmentation, rather than on transactional leadership's potential augmentation. Moreover, individual performance was not included as a criterion in their meta-analysis. Therefore, evidence on the possible augmentation effect for transactional leadership, relative to the outcome of follower performance, is uncertain. The present replication of Schriesheim et al.'s finding of an augmentation effect for transactional leadership relative to individual performance (notwithstanding the differences in the sampling procedures of the two studies) raises the prospect that contingent reward may be of greater potential value to explaining performance than heretofore acknowledged.

\section{Summary}

House's (1996) extension of path-goal theory sought to make the theory more comprehensive by including behaviors from transformational and transactional views of leadership. The present findings underscore the potential utility of House's extended theory in accounting for interactive and augmentation effects. In addition, the present evidence of augmentation effects, in conjunction with negative moderation effects, suggests that transactional leader behaviors may have greater predictive value than previously assumed.

\section{References}

Aiken, L. S., \& West, S. G. (1991). Multiple regression: Testing and interpreting interactions. Newbury Park, CA: Sage.

Barnett, K., McCormick, J., \& Conners, R. (2001). Transformational leadership in schools - Panacea, placebo or problem? Journal of Educational Administration, 39, 24-46.

Bass, B. M. (1985). Leadership and performance beyond expectations. New York, NY: Free Press.

Bass, B. M. (1990). Bass and Stogdill's handbook of leadership (3rd ed.). New York, NY: Free Press.

Bass, B. M. (1997). The ethics of transformational leadership. Kellogg leadership studies project: Transformational leadership, working papers. College Park, MD, Academy of Leadership Press.

Bass, B. M., \& Avolio, B. J. (1993). Transformational leadership: A response to critiques. In M. Chemers \& R. Ayman (Eds.), Leadership theory and research: Perspectives and directions (pp. 49-80). New York, NY: Academic Press.

Bass, B. M., \& Avolio, B. J. (1994). Improving organizational effectiveness through transformational leadership. Thousand Oaks, CA: Sage.

Bass, B. M., Avolio, B. J., Jung, D. I., \& Berson, Y. (2003). Predicting unit performance by assessing transformational and transactional leadership. Journal of Applied Psychology, 88, 207-218.

Bliese, P. D. (2000a). Multilevel random coefficient modeling in organizational research. In F. Drasgow \& N. Schmitt (Eds.), Measuring and analyzing behavior in organizations: Advances in measurement and data analysis (pp. 401-445). San Francisco, CA: Jossey-Bass.

Bliese, P. D. (2000b). Within-group agreement, non-independence, and reliability: Implications for data aggregation and analysis. In K. J. Klein \& S. W. J. Kozlowski (Eds.), Multilevel theory, research, and methods in organizations: Foundations, extensions, and new directions (pp. 349-381). San Francisco, CA: Jossey-Bass. 
Bycio, P., Hackett, R. D., \& Allen, J. S. (1995). Further assessments of Bass's (1985) conceptualisation of transactional and transformational leadership. Journal of Applied Psychology, 80, 468-478.

Cammann, C., Fichman, M., Jenkins, D., \& Klesh, J. (1983). Assessing the attitudes and perceptions of organization members. In S. E. Seashore, E. E. Lawler, P. Mirvis, \& C. Cammann (Eds.), Assessing organizational change (pp. 71-138). New York, NY: Wiley.

Cohen, J., Cohen, P., West, S. G., \& Aiken, L. S. (2003). Applied multiple regression/correlation analysis for the behavioral sciences (3rd ed.). Mahwah, NJ: Erlbaum.

Conger, J. A., \& Kanungo, R. A. (1987). Toward a behavioral theory of charismatic leadership in organizational settings. Academy of Management Review, 12, 637-647.

Eden, D. (1998). The paradox of school leadership. Journal of Educational Administration, 36, 249-261.

Education, California Department of (2001). California public school directory-2001. Sacramento, CA: California Department of Education Press.

Evans, G. (1970). The effects of supervisory behavior on the path-goal relationship. Organizational Behavior and Human Performance, 5, 277-298.

Glick, W. H. (1985). Conceptualizing and measuring organizational and psychological climate: Pitfalls in multilevel research. Academy of Management Review, 10, 601-616.

Hofmann, D. A. (1997). An overview of the logic and rationale of hierarchical linear models. Journal of Management, 23, 723-744.

House, R. J. (1971). A path-goal theory of leader effectiveness. Administrative Science Quarterly, 16, 321-338.

House, R. J. (1996). Path-goal theory of leadership: Lessons, legacy, and a reformulated theory. Leadership Quarterly, 7, 323-352.

House, R. J., \& Dessler, G. (1974). The path-goal theory of leadership: Some post-hoc and a priori tests. In J. Hunt \& L. Larson (Eds.), Contingency approaches to leadership (pp. 29-55). Carbondale, IL: Southern Illinois University Press.

House, R. J., \& Mitchell, T. R. (1974). Path-goal theory of leadership. Journal of Contemporary Business, 3, 81-97.

House, R. J., \& Shamir, B. (1993). Toward the integration of transformational, charismatic, and visionary theories. In M. Chemers \& R. Ayman (Eds.), Leadership theory and research: Perspectives and directions (pp. 81-107). Orlando, FL: Academic Press.

Howell, J. M., \& Avolio, B. J. (1992). The ethics of charismatic leadership: Submission or liberation? Academy of Management Executive, 6, 43-54.

Hox, J. (1998). Multilevel modeling: When and why. In I. Balderjahn, R. Mather, \& M. Schader (Eds.), Classification, data analysis, and data highways (pp. 147-154). New York, NY: Springer Verlag.

Ingram, P. D. (1997). Leadership behaviours of principals in inclusive educational settings. Journal of Educational Administration, 35, 411-427.

Johnson, P. O., \& Neyman, J. (1936). Tests of certain linear hypotheses and their implications to some educational problems. Statistical Research Memoirs, 1, 57-93.

Judge, T. A., \& Piccolo, R. F. (2004). Transformational and transactional leadership: A meta-analytic test of their relative validity. Journal of Applied Psychology, 89, 755-768.

Kreft, I. G. G. (1996). Are multilevel techniques necessary? An overview, including simulation studies. Unpublished paper, California State University, Los Angeles.

Leithwood, K. (1994). Leadership for restructuring. Educational Administration Quarterly, 30, 498-518.

Leithwood, K., \& Jantzi, D. (1997). Explaining variation in teachers' perceptions of principals' leadership: A replication. Journal of Educational Administration, 35, 312-331. 
Lindquist, E. F. (1940). Statistical analysis in educational research. Boston, MA: Houghton- Mifflin.

Podsakoff, P. M., Bommer, W. H., Podsakoff, N. P., \& MacKenzie, S. B. (2005). Relationships between leader reward and punishment behavior and subordinate attitudes, perceptions, and behaviors: A meta-analytic review of existing and new research. Organizational Behavior and Human Decision Processes, 99, 113-142.

Podsakoff, P. M., MacKenzie, S. B., \& Bommer, W. H. (1996). Transformational leader behaviors and substitutes for leadership as determinants of employee satisfaction, commitment, trust, and organizational citizenship behaviors. Journal of Management, 22, 259-298.

Podsakoff, P. M., MacKenzie, S. B., Lee, J. Y., \& Podsakoff, N. P. (2003). Common method biases in behavioral research: A critical review of the literature and recommended remedies. Journal of Applied Psychology, 88, 879-903.

Podsakoff, P. M., MacKenzie, S. B., Moorman, R. H., \& Fetter, R. (1990). Transformational leader behaviors and their effects on followers' trust in leader, satisfaction, and organizational citizenship behaviors. Leadership Quarterly, 1, 107-142.

Podsakoff, P. M., \& Organ, D. W. (1986). Self-reports in organizational research: Problems and prospects. Journal of Management, 12, 31-41.

Podsakoff, P. M., Toder, W. D., Grover, R. A., \& Huber, V. L. (1984). Situational moderators of leader reward and punishment behaviors: Fact or fiction? Organizational Behavior and Human Performance, 34, 21-63.

Raudenbush, S. W., \& Bryk, A. S. (2002). Hierarchical linear models: Applications and data analysis methods (2nd ed.). Thousand Oaks, CA: Sage.

Raudenbush, S.W., \& Liu, X. (2000). Statistical power and optimal design for multisite randomized trials. Psychological Methods, 5, 199-213.

Schriesheim, C. A., Castro, S. L., Zhou, X. T., \& DeChurch, L. A. (2006). An investigation of pathgoal and transformational leadership theory predictions at the individual level of analysis. Leadership Quarterly, 17, 21-38.

Schriesheim, C. A., Cogliser, C. C., \& Neider, L. L. (1995). Is it trustworthy? A multiple levels-ofanalysis reexamination of an Ohio State leadership study, with implications for future research. Leadership Quarterly, 6, 111-145.

Schriesheim, C. A., \& Neider, L. L. (1996). Path-goal leadership theory: The long and winding road. Leadership Quarterly, 7, 317-321.

Spector, P. E. (1987). Method variance as an artifact in self-reported affect and perceptions at work: Myth or significant problem? Journal of Applied Psychology, 72, 438-443.

Spector, P. E. (2006). Method variance in organizational research: Truth or urban legend? Organizational Research Methods, 9, 221-232.

Waldman, D. A., Bass, B. M., \& Yammarino, F. J. (1990). Adding to contingent-reward behavior: The augmenting effect of charismatic leadership. Group and Organization Studies, 15, 381-394.

Wofford, J. C., \& Liska, L. Z. (1993). Path-goal theories of leadership: A meta-analysis. Journal of Management, 19, 857-876. 